\title{
Employee Satisfaction Survey At Loksuvidha Pvt.Ltd
}

\author{
${ }^{1}$ Mr. Nimish Laddhad, ${ }^{2}$ Mr.KamleshLaddhad, ${ }^{3}$ Ms. Divyani Ghatole \\ ${ }^{1}$ Chief Executive Officer, Loksuvidha Pvt.Ltd \\ ${ }^{2}$ Chief Technology Officer, Loksuvidha Pvt.Ltd \\ ${ }^{3}$ Student, Shri Ramdeobaba College of Engineering \& Management, Nagpur. \\ Email:nimish.laddhad@Loksuvidha.com,ghatoledv_1@rknec.edu
}

\section{Received: $20^{\text {th }}$ September 2018, Accepted: $11^{\text {th }}$ October 2018, Published: $31^{\text {st }}$ October 2018}

\begin{abstract}
The purpose of the present exploratory research is to study the Employee Satisfaction at LoksuvidhaPvt.Ltd. LoksuvidhaPvt.Ltd is a two-wheeler financing firm operating in Maharashtra, Madhya Pradesh \&Chattisgarh with 200+ employees working for them. The LoksuvidhaPvt.Ltd focuses on Middle Class and poor population of India who face problem in acquiring loans thus Loksuvidha becomes guarantor for them. Employee satisfaction helps organisation to understand the nerve of employees. It provide insight about what is going right for the employees \& if there is an opportunity to improve any of the organisational policies. In the current research, responses are sought from employees on questionnaire that is prepared keeping in mind various parameters specially identified for the research pupose. The Focus of this research paper is to conduct an employee satisfaction survey where the questionnaire will cover topics such as working condition, relationship with the organisation, performance appraisal, utilisation of skills $\&$ abilities, work assignment $\&$ grievance handling mechanism. One Sample Z Test is utilised for analysing the data.With the help of this research we intend to find out the satisfaction of employees at Loksuvidha.
\end{abstract}

\section{Keywords}

Employee Satisfaction, Organisation, Policies

\section{Introduction}

Organisation play a very vital role when it comes to satisfaction of employees. The more the organisation takes care of employees the more satisfied they are. The employees expectations grows as they spend more time in the organisation, and they relate their expectations directly with the satisfaction. There are more factors that contribute to their satisfaction that are smooth working, their relationship with their peers, support from the organisation, their qualifications and its implementation, etc. If there is smooth balance of these factors in the organisation then the employees will be highly satisfied.

In this Research Paper, our focus was to measure the satisfaction level of employees at Loksuvidha Pvt.Ltd. Loksuvidha Pvt.Ltd runs on a business model where they focus on middle class and lower class population who face problems in acquiring the loans. They believe that there are some target segment who can't approach banks for the loans directly due to either low level of educations \& awareness or due to no proof of documents. Therefore for such people the Loksuvidha act as guarantor. They provide loans to their customers at a certain interest rate that they can give it back to Loksuvidha at very low EMIs. Majorly Loksuvidha started this so that their target customers can buy two-wheelers for their use, as it was observed by the founders of the Loksuvidha Pvt.Ltd that their target customer wants two-wheeler for their use but can't afford it by paying wholesome amout or due to unavailabilitty of documents with them. But now the business model is modified. Now they don't provide loans for two-wheeler only, but for other reasons also such as loans for paying school, college fees.

First the work in the organisation was unorganised. The employees would approach the top management directly, this was happening because there was no presence of hierarchy at the early stage. But now there is presence of hierarchy, a system i.e., mobile based applications, and computer systems in the organisation for the smooth running of business. The customer base also increased over a period of time. Due to this, the owners of the business were motivated and continued the business as they were able to see their business grow.

The LoksuvidhaPvt. Ltd have some pillars. These pillars are nothing but the stakeholders of the business, the promoters of the business, the employees, the customers, the institutions with whom the Loksuvidha have tiedup \& the banks for trusting them. For now there are three states where Loksuvidha have their operations that are Madhya Pradesh, Chattisgarh \& Maharashtra, and the cities are Chhindwara, Indore, Dewas, Betul, Raipur, Nashik, Dhule, Jalgaon, Nagpur, Nanded, Wardha, Jalna, Parbhani, Chandrapur, Latur.

Employee satisfaction is one of the most popular topics when it comes to research in human resources. Recently, the topic boosted further as it is found that employees are dissatisfied in the organisation due to more competitive environment, rising expectations of industry, technological changes,etc. For this reason lot of researchers involved themselves in this kind of research. One such research is presented by EmiraKozharevic ( $5^{\text {th }}$ April, 2017).In the research paper, the researchers investigated about the job satisfaction in banking sectors. 
The parameters they considered were demographic characteristics, management \& supervision, monetary compensation, non-monetary recognition, work environment, job responsibility \& type of tasks, social atmosphere at work and general satisfaction with life. The researchers explained that how recession impacted on the lives of the employees working in banking sector, majorly in Developing Countries. The researchers conducted the survey where number of respondents were around 500. The objective of the research was to determine the overall level of satisfaction, to identify major factors that influence the level of satisfaction of employees and to provide suggestions. At the end, the researchers concluded that the involvement of the employees in decision making must be increased so that they can understand and contribute that whats happening around them. Also, the employees are satisfied with their monetary compensation and timely pay. But they are dissasfied with their working hours.

Another research was presented by Masood UI Hassan (Sci.IntLahore,25,4,957-963,2013). The main purpose of this study was to analyse the relationship among employee satisfaction, customer satisfaction and the financial performance of the Insurance Corporation of Pakistan. They conducted a survey where they asked employees as well as the Insurance Buyers to fill the questionnaire. There main research was around that there is significant relationship between satisfaction of customers \& satisfaction of employees. They concluded that customer satisfaction partially contributes towards employee satisfaction.

\section{Materials and Methods}

This research is conducted in very systematic manner. First the researchers approached the organisation for the discussionto employ the topic. Organisation was keen to undertake the study as they were eager to understand the perception of employee towards the various policies adopted in the organisation. There are number of research conducted on the Employee Satisfaction on different parameters. Based on the discussion, list of parameters were identified that was shared with the organisation. Following parameters were finally decided for designing the Questoinnaire.

1. Working Condition

2. Relationship With The Organisation

3. Performance Appraisal

4. Utilisation Of Skills \& Abilities

5. Work Assignment

6. Grievance Handling Mechanism.

For every parameter, 5 positive statements were identified in the questionnaire. Final questionnaire had 30 statements in all. The respondents were asked to give their responses on 5 point Likert Scale from Strongly Agree to Strongly Disagree. Few questions were open-ended so that the researchers can get the suggesstions from the employees about improvements int the organisation itself.

There were 53 respondends from which the data was collected. The final conclusion is given on the basis of survey conducted, discussion with the employees and on the basis of observations during the survey. the type of research is descriptive in nature.

The objectives of the research are listed below:

1) To identify the factors that contribute to employee satisfaction.

2) To understand the employees behaviour in the organisation and the problems related to satisfaction.

3) To conduct an employee satisfaction survey at LoksuvidhaPvt..Ltd

4) To understand level of satisfaction of employees.

For the analysis, the researchers formulated some hypothesis. On the basis of the sample size the researchers done the analysis on the basis of One-sample Z-test.

Null Hypothesis: -The employees are not satisfied with the organisation.

Alternate Hypothesis : - The employees are satisfied with the organisation.

Primary source of data was collected through questionnaire.Discussions with the employees\& observations during the survey are also included in the analysis of the data collected. Journals, books, websites etc are used as secondary source of data.

The survey included various demographic information associated with the respondends that are mentioned below:

1) Department

2) Years of service

3) Educational Qualification

4) Gender

5) Marital Status

Departments present in the organisation are: Recovery, Finance, Sales, Clearing, Operations, Accounts Section, Information Technology, Training.In terms of years of service, the services of employees in the organisation is 
ranging from 4 months to 6 years.Majority of employees were Graduates and very few are post graduates in the organisation. This is because the recovery and sales department are the largest ones in the organisation where according to the work profile graduation is sufficient as educational qualification to perofrm that job. Out of 53, 34 respondents are females and 19 respondends are males, and 31 respondends were unmarried and 22 were married.

\section{Results and Discussion}

Below are given the values that were used to calculate $\mathrm{Z}$ value on the basis of which we concluded that the hypothesis was accepted or rejected.

For the research,

Population mean $=3$

Z-critical value $=1.68$

If the calculated value comes more than critical value then the null hypothesis will be rejected and vice-versa.

\begin{tabular}{|l|l|l|l|l|l|}
\hline Parameters & $\begin{array}{l}\text { Sample } \\
\text { Mean }\end{array}$ & $\begin{array}{l}\text { Standard } \\
\text { Deviation }\end{array}$ & $\begin{array}{l}\text { Square } \\
\text { Root of N }\end{array}$ & $\begin{array}{l}\text { Standard } \\
\text { Error }\end{array}$ & Z-value \\
\hline Working Conditions & 3.8207547 & 0.6324125 & 7.2801099 & 0.0868685 & 9.4482391 \\
\hline Relationship with the organisation & 3.9669811 & 0.6241104 & 7.2801099 & 0.0857282 & 11.279621 \\
\hline Performance appraisal & 3.490566 & 0.7594948 & 7.2801099 & 0.1043246 & 4.7023029 \\
\hline Utilisation of skills \& abilities & 3.5990566 & 0.7093802 & 7.2801099 & 0.0974409 & 6.1478992 \\
\hline Work assignment & 3.7830189 & 0.6776617 & 7.2801099 & 0.093084 & 8.4119609 \\
\hline Grievance handling mechanism & 3.7075472 & 0.6235287 & 7.2801099 & 0.0856483 & 8.2610805 \\
\hline
\end{tabular}

Table 1: Descriptive Statistics \& Computed Z-value

From the above analysis, it is interpretated that the overall employees are satisfied with the organisation. In all the parameters the null hypothesis was rejected and the alternate hypothesis is accepted. This shows that on all the six parameters employees are happy with the organisation. The computed Z-value is far more than the Zcritical value, this shows that most the employees choosed "strongly agree" and "agree" option for the positive sentences, due to which the computed $\mathrm{Z}$ values ranged far from $\mathrm{Z}$-critical value.

\section{Conclusion}

The organisation takes good care of their employees as most of the employees are satisfied with the organisation. The employees of LoksuvidhaPvt.Ltd feels that the working conditions are in favour of them which is a positive contribution towards their satisfaction. Also, the relationship of the employees with their collegues are good so help the employees to work happily in the organisation. The organisation have a good system of appraising the employees therefore the employees are satisfied with the pay also. While recruiting, the top management makes sure that the person they are recruiting have all the skills \&abilties according to the job role. This helped them to perform their task smoothly and the employees were able to utilise their skills \&abilties. The work assignments given to the employees are interesting \& challenging, therefore the employees are motivated towards their work. Also it is not overloaded unnecessarily, therefore they get sufficient time to finish their work. For handling grievances, the organisation takes continuous feedback from the employees, also the employees can approach the assigned person for grievances anytime, if they are facing any problem. Due to this even if some grievances occurs, that are solved on primary stage only. Therefore, it is concluded that employees of LoksuvidhaPvt.Ltd are satisfied with the organisation.

\section{References}

1. Uday Kumar Haldar\&Juthika Sarkar, Human Resource Management, OXFORD Higher Education, 2012, Page 384-387.

2. K Aswathappa, Human Resource Management, $7^{\text {th }}$ edition, Text and Cases, McGraw Hill Education (India) Private Limited, 2013, Page 368-382.

3. Job satisfaction at banking sector employees in the federation of Bosnia and Herzegovina 
https://www.researchgate.net/publication/315789237_Job_satisfaction_of_banking_sector_employees in_the_Federation_of_Bosnia_and_Herzegovina(02/09/2018)

4. Impact of employee satisfaction on financial performance through mediating effect of customer satisfaction: A case study of life insurance corporation of Pakistan.

http://www.sci-int.com/pdf/133484511651--957-963-Shanzaf-Masood-BZ\%20\%20composed\%20-

Uni-Multanl.pdf(02/09/2018)

5. Empirical study of Employee Job Satisfaction

http://www.iosrjournals.org/iosr-jbm/papers/ndbmr-volume-1/D.pdf(13/09/2018) 